\title{
Giant sialolith mimicking an impacted tooth
}

\author{
Kumar Nilesh, ${ }^{1}$ Huzaifa S Kothi, ${ }^{2}$ Aaditee Vande, ${ }^{3}$ Sridhar Reddy ${ }^{4}$
}

${ }^{1}$ Department of Oral and Maxillofacial Surgery, Krishna Institute of Medical Sciences Deemed University, Karad, Maharashtra, India ${ }^{2}$ Department of Oral and Maxillofacial Surgery, Oral Care Centre, Godhra, Gujrat, India ${ }^{3}$ Department of Prosthodontics, Crown and Bridge, Krishna Institute of Medical Sciences Deemed University, Karad, Maharashtra, India ${ }^{4}$ Department of Oral and Maxillofacial Surgery, Hyderabad Government Dental College and Hospital, Hyderabad, Telangana, India

\section{Correspondence to}

Dr Kumar Nilesh;

drkumarnilesh@yahoo.com

Accepted 18 February 2020

\section{DESCRIPTION}

A 37 year-old male patient was referred by private dental practitioner to oral surgery clinic for surgical removal of an impacted mandibular tooth, which was believed to be the cause of pain at the right side of the lower jaw and radiating to the right submandibular area. Pain was acute and intermittent in nature and aggravated on chewing and during eating. Diffuse swelling was seen over right submandibular region with no local rise in temperature. Further clinical palpation for evaluation of swelling was not possible due to complaint of pain by patient. Intraoral examination showed reduced mouth opening with interincisal distance of $15 \mathrm{~mm}$. Diffuse swelling was seen over right floor of the mouth. Orthopantomogram of patient showed both jaws with normal component of teeth. Horizontally impacted mandibular third molars were seen. A linear radiopacity was noted extending coronally between tooth number 44 and 45 , and extending apically below the roots of 46 , resembling an impacted supernumerary tooth (figure 1). To investigate further, ultrasonography (USG) was advised to study the soft tissue swelling over right submandibular region. A $20 \mathrm{~mm}$ linear echogenic focus with acoustic shadow was seen in the right submandibular duct. The right submandibular gland appeared swollen with hypoechogenic echotexture (figure 2). Diagnosis of giant sialolith was made based on the findings of USG. Surgical removal of the sialolith was planned and executed under general anaesthesia. An intraoral

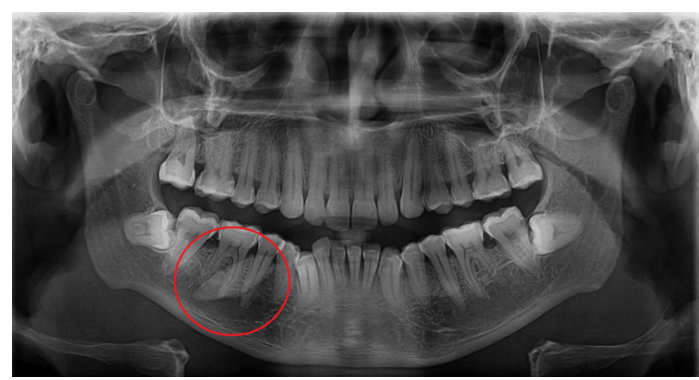

Figure 1 Orthopantomogram showing a linear radiopacity overlapping the lower right second premolar and first molar.
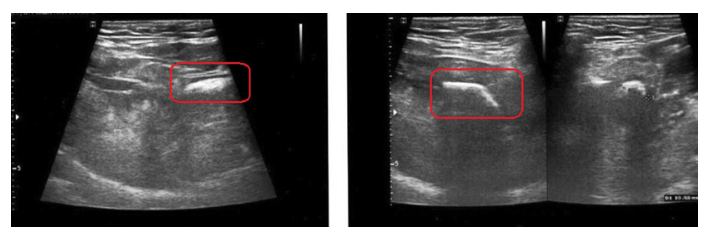

Figure 2 Ultrasonography of the submandibular region showing sialolith.

\section{Learning points}

- Sialoliths, which measure $>15 \mathrm{~mm}$ are rare and are termed as giant sialoliths. ${ }^{12}$ In the present case, appearance of giant sialolith on orthopantomogram, resembling impacted supernumerary tooth lead to misdiagnosis.

- Such presentation is rare. ${ }^{3}$ Following features should be used to differentiate sialolith from an impacted tooth on orthopantomogram; lack of sclerotic margins of lamina dura, absence of radiolucent central pulp chamber and differential radiolucency between enamel and dentin.

- Ultrasonography (USG) is an important diagnostic aid in medicine for detecting pathologies of abdomen, kidney, liver and breast. It is can be used to diagnose various oral lesions, including lesions of salivary gland vascular malformations, orofacial abscess and cysts/tumours of jaw. It safe, quick, non-invasive and relatively inexpensive, with high sensitivity and specificity in diagnosing oral soft tissue pathology and superficial jaw lesion. ${ }^{4}$

- Diagnosing a common pathology with its usual clinical finding is straightforward. ${ }^{5}$ However, rarely a diagnostic finding may be misinterpreted, as the finding of linear radiopacity mimicking an impacted tooth on orthopantomogram in the present case. Use of correct diagnostic aid, like USG, helps in arriving at correct diagnosis, thus avoiding wrong treatment.

incision was placed over the mucosa of floor of mouth on right side. Attention was given to identify and avoid the opening of submandibular duct opening at floor of mouth on either side of lingual frenum. Blunt dissection was done, and the Wharton's duct with sialolith was identified. A stay suture was passed around the duct posterior to sialolith to prevent its slippage deeper into the duct. An incision was placed over the duct and the sialolith was removed. The duct wall was approximated and allowed to heal primarily. The mucosal incision was closed with resorbable 3-0 polyglactin interrupted sutures. On postoperative follow-up, the patient had uneventful healing and the symptoms of pain and swelling resolved.

Contributors KN and HSK were involved in clinical evaluation and assessment of the case. $\mathrm{AV}, \mathrm{KN}$ and $\mathrm{SR}$ were involved in preparation and final approval of the manuscript.

Funding The authors have not declared a specific grant for this research from any funding agency in the public, commercial or not-for-profit sectors. 
Competing interests None declared.

Patient consent for publication Obtained.

Provenance and peer review Not commissioned; externally peer reviewed.

\section{REFERENCES}

1 Arslan S, Vuralkan E, Cobanog lu B, et al. Giant Sialolith of submandibular gland: report of a caset. J Surg Case Rep 2015;2015:rjv043.
2 Gadve V, Mohite A, Bang K, et al. Unusual giant Sialolith of Wharton's duct. Indian J Dent 2016;7:162-4.

3 Bhullar RS, Dhawan A, Bhullar K, et al. Giant submandibular gland duct sialolith mimicking an impacted canine tooth. Natl J Maxillofac Surg 2015:6:89-92.

4 Rama Mohan K, Koteswara Rao N, Leela Krishna G, et al. Role of ultrasonography in oral and maxillofacial surgery: a review of literature. J Maxillofac Oral Surg 2015;14:162-70.

5 Nilesh K, Vande AV, Tewary S. Bluish sub-mucosal alveolar swelling: a diagnostic dilemma. J Stomatol Oral Maxillofac Surg 2017;118:405-6.

Copyright 2020 BMJ Publishing Group. All rights reserved. For permission to reuse any of this content visit

https://www.bmj.com/company/products-services/rights-and-licensing/permissions/

BMJ Case Report Fellows may re-use this article for personal use and teaching without any further permission.

Become a Fellow of BMJ Case Reports today and you can:

- Submit as many cases as you like

Enjoy fast sympathetic peer review and rapid publication of accepted articles

Access all the published articles

Re-use any of the published material for personal use and teaching without further permission

\section{Customer Service}

If you have any further queries about your subscription, please contact our customer services team on +44 (0) 2071111105 or via email at support@bmj.com.

Visit casereports.bmj.com for more articles like this and to become a Fellow 